\title{
Subjective Health and Subjective Well-Being (The Case of EU Countries)*
}

\author{
A. Gataūlinas' ${ }^{1}$, M. Banceviča ${ }^{2}$ \\ ${ }^{1}$ Institute of Sociology, Lithuanian Social Research Centre, Vilnius, Lithuania \\ ${ }^{2}$ Department of Political Science, Faculty of Social Sciences, University of Latvia, Riga, Latvia \\ Email: arturas.gataulinas@gmail.com, marta.bancevica@gmail.com
}

Received 25 July 2014; revised 15 August 2014; accepted 22 August 2014

Copyright (C) 2014 by authors and Scientific Research Publishing Inc.

This work is licensed under the Creative Commons Attribution International License (CC BY). http://creativecommons.org/licenses/by/4.0/

\section{(c) (i) Open Access}

\begin{abstract}
Article presents the concept of subjective health in the context of the structure of subjective wellbeing. We emphasize the structural link between satisfaction with health as a life domain and satisfaction with a life as a whole within cognitive part of subjective well-being. To explain the link between life satisfaction as a whole and satisfaction with health we apply Needs Conceptual Model of Subjective Well-Being and bottom-up approach. We recognize that objective life domains-life circumstances are mirrored and evaluated by human consciousness. The more or less favourable objective life circumstances are, the better or worse is the satisfaction with them by an individual. From the very general perspective, in empirical part of the article, we present both objective and subjective health situation and the life satisfaction in EU countries. We use Eurostat and European Values Survey data. Satisfaction of needs leads to increased level of subjective weal-being. When objective health by an individual is being compared to the certain standard, it fits in to the system of overall satisfaction with life. It means that the whole process starts at the point of objective health and ends at the point of life satisfaction.
\end{abstract}

\section{Keywords}

Satisfaction with Life, Subjective Well-Being, Satisfaction with Health, Subjective Health, Needs Conceptual Model of Subjective Well-Being

\section{Introduction}

Subjective aspects in the history of social science have been neglected for a long time. There was a strong belief that human feelings and life evaluations are too subjective for the valid policy guidelines. Mainly easily detect-

*This work has been supported by the European Social Fund within the project "Support for Doctoral Studies at University of Latvia". 
able and measurable objects like money, wealth, life expectancy, absence of certain medical condition etc. were the object for the research. This approach became empirical science in the $17^{\text {th }}$ century and is related to W. Petty's scientific activity to estimate national wealth and income of England. In the mid $20^{\text {th }}$ century, with the publishing of first national accounts, this income-based approach reached its apogee. The concepts and measurements related to this approach have been developed. In 1942, Cottam and Mangus (1942) introduced the concept of standard of living that is widely accepted in well-being research.

The situation began to change slowly from the mid $20^{\text {th }}$ century, when the subjective aspects of social interactions were recognized and started to be measured. Even as early as 1925 Flugel first wrote about perception of subjective well-being (as cited in Snyder \& López, 2009). In 1965, Cantril, in his study about human interest models for the first time, used the concept of subjective well-being (as cited in Kahneman et al., 2003). Besides that, relations between subjective and objective aspects have become very important. Thus as Killoran and Kelly (2010) reasonably point out that in context of the social science there is a possibility to speak at least about two perspectives of evidence: objective and subjective. But regardless of whether, these two perspectives can define the objective content (Killoran \& Kelly, 2010). In some fields, measuring subjective aspects could compensate the lack of valid objective data. In the field of health science as Fotso and Kuate-Defo (2005), the concept of the subjective perception has not been widely used and main importance was given to the "fact" assessment. And that made it difficult in some countries where there is a limited data on health-related benefits to estimate the impact of social-economic welfare on health situation of the society.

For the health studies from the perspective of the social science it is important to emphasize link between health and the individual's subjective experience of his/her living conditions. This is because different types of critical factors related with the health problems are psychosocial (French et al., 2010). That means that health requires new solutions for the society's subjective processes (Levenstein \& Wooding, 1997). Social determinants of health provide significant opportunities for the understanding which social structures determine the mentally negative effects and social costs. Social reforms based on those social determinants of health could potentially improve not only health but also quality of life of society (Siegel, 1994).

Based on those, above outlined subjectively oriented implications for the social and health sciences, in this article we are going to present the concept of subjective health in the context of the structure of subjective well-being. As well we are going to show that the concept of subjective health could be derived out of the structure of subjective well-being. As well we are going, based on the existing data possibilities and limitations, to determine relation between objective health situation, subjective health and subjective well-being. For that purpose we are going to employ European Values Study micro and macro data and Eurostat macro data to find an association between the variables.

The task of our research is to investigate the interrelation between subjective health and subjective well-being in the context of EU countries.

\section{Structure of Subjective Well-Being and the Place of Subjective Health in It}

In general terms, subjective well-being research deals with people's evaluations of their life situations, as well as mood and emotions. Subjective well-being could be described as a product of interaction between human consciousness and individual's living environment. Ideas on the structure of subjective well-being were initially presented by Bradburn (1969) and later on were developed by Diener $(1984,2006)$. Since then that structure of the concept have become very popular among researchers of subjective well-being and have been used or at least mentioned in almost every research paper that deals with subjective well-being. For instance that structure of subjective well-being is mentioned in works of the Pavot (2008), Schimmack (2008), Vitters $\varnothing$ and Nilsen (2002), Gallagher (2009) etc. Based on that structure, the concept of subjective well-being is defined by Diener (2006: pp. 399-400) as a phenomenon that "....refers to all of the various types of evaluations, both positive and negative, that people make of their lives. It includes reflective cognitive evaluations, such as life satisfaction and work satisfaction, interest and engagement, and affective reactions to life events, such as joy and sadness."

The graphical portray of the structure of subjective well-being refers to a two major components-affective and cognitive (Figure 1). Affective component could be divided on a horizontal level in to two smaller unitspositive and negative affect. Positive affect is defined by Diener (2006) as pleasant mood and emotions. In turn negative affect is defined by the same author as unpleasant mood and emotions. In general terms affective component reflects the unconscious side of subjective well-being that accompany life events of an individual.

In turn, cognitive component consists on a three hierarchically organized units such satisfaction with life as a whole, multidimensional and domain satisfactions. Cognitive components reflect evaluative side of subjective 


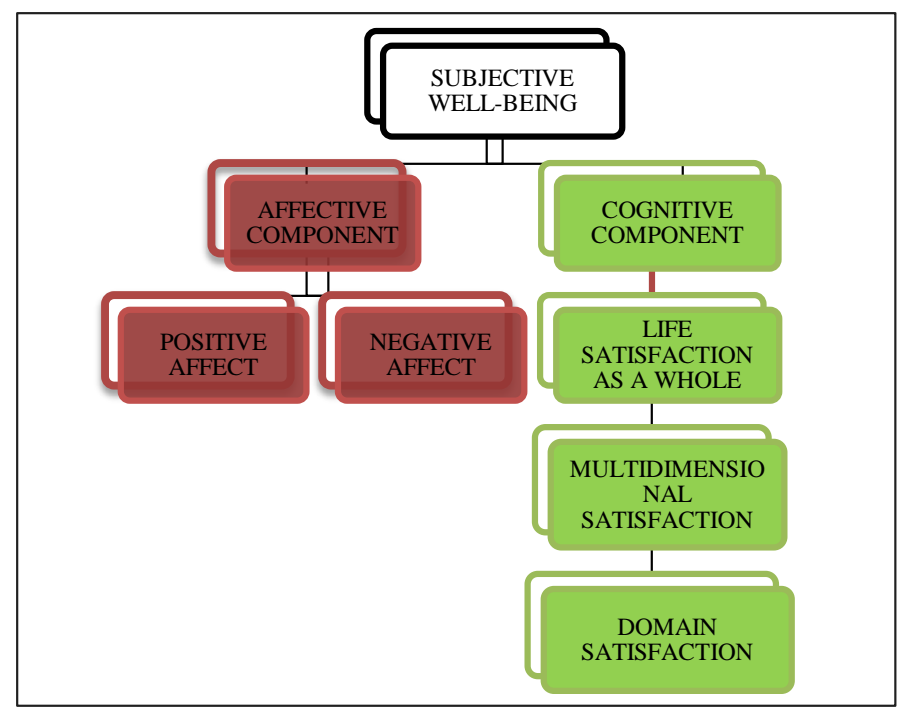

Figure 1. Structure of subjective well-being. Graphical presentation based on ideas of Diener (2006) and Pavot (2008).

well-being: that is it appears when the life situation is being compared to certain standards such as individual's life situation in the past, average situation of society as a whole, individual goals etc. Diener (2006) life satisfaction defines as individual's appraisal of life as a whole. In turn domain satisfaction is defined by Diener (2006) as appraisal of separate major life domains. Pavot (2008) defines multidimensional satisfaction as a set of important life domains. Thus, on the contrary affective component of subjective well-being, the cognitive component encompasses conscious aspects of individual's subjective experience.

There could be distinguished infinite number of life domains that can be linked to general subjective wellbeing in various ways (Figure 2). Those domains could be interpreted as a niche for the factors of subjective well-being. Subjective well-being is influenced by a variety of life factors (Boarini et al., 2012). Some of them are more objective and some more subjective (Sîlis, 2010). Due to our thematic focus, in this article, we are going to emphasize the structural link between satisfaction with health and satisfaction with a life as whole. According to Johnston et al. (2007) subjective health reflects "...what individual feels about their own health at a given point of time".

Health is a sensitive variable in relation to the qualitative and quantitative material and social life changes (Beverley, 2008). It may seem that the health enhancement includes happiness donation. However studies indicate that the health itself could be impacted by happiness and as well on several specific aspects of social welfare (Titterton, 2005). Psychosocial circumstances indicate subjective psychological and emotional consequences arising as a result of the objective characteristics of the social structure. In this view, health refers to the social order and material life impact on human subjectivity (Bendelow, 2009).

According to Stewart and Ware (1998) concept of health includes physical, mental, social functioning and well-being of the individual. In turn The World Health Organization provides us with official definition of health - the absence of disease and weakness and as well as a complete mental and physical well-being (World Health Organization, 1946). Paradoxically the mortality rates are often used for measuring the health because a universal health measuring indicator does not exist (McDowel, 2006). It is also often used life expectancy (McCracken \& Phillips, 2012) or self-rated health variables (Liu, 2012). In our empirical part of this article we are going to use life expectancy and self-rated health indicator as one of our main variables.

Health might be described by two perspectives: health can be judged by the "fact", looking at diagnosis, mortality rates and other health condition characterizing variables. But also it is possible to see the health through self-assessment (Pardeck et al., 1998). It has been proved that the health self-esteem can be an indicator, predicting and identifying the health care system opportunities, mortality and other relevant variables characterizing the health (DeSalvo et al., 2005). There is a relationship between characterizing objective health data and health self-esteem. This could be explained by the fact that the overall health self-assessment includes all health characterizing aspects and in turn, human feelings have an impact on health (Wahl, 2006). Quite often, self-assess- 


\begin{tabular}{|c|c|}
\hline \multirow{7}{*}{$\begin{array}{l}\text { Domain } \\
\text { satisfaction }\end{array}$} & Marital satisfaction \\
\hline & Housing satisfaction \\
\hline & Satisfaction with leisure \\
\hline & Job satisfaction \\
\hline & Satisfaction with income \\
\hline & Satisfaction with health \\
\hline & Etc. \\
\hline
\end{tabular}

Figure 2. Satisfaction with various life domains.

ment of health is ignored and excluded from the agenda of relevant policies (Diener et al., 2009). This would imply that policies that deny subjective aspects of health could contradict to society's expectations and needs.

\section{Interrelation between Structural Parts of Subjective Well-Being and the Needs Conceptual Model of Subjective Well-Being}

In the structure of subjective well-being presented above, all the parts are systematically interrelated to each other. They are not just the sum of separate parts, but a system where separate parts are standing in particular relation to each other. There are many studies that are stressing one or another part of that systematic interrelation. Here we want to emphasize interrelation within cognitive part of subjective well-being, because only satisfaction with health will be analysed in this article.

Interrelations within cognitive part of subjective well-being could be understood as having the two directions: bottom-up or top-down. As well those interrelations could be named as a bottom-up and top-down theories of subjective well-being. Bottom-up interrelation means that satisfaction with separate life domains determinates life satisfaction as a whole. Top-down approach means that life satisfaction as a whole determinates satisfaction with separate life domains (Schimmack, 2008; Pavot, 2008; Headey, 1991; Lucas, 2004). Galinha and PaisRibeiro (2011) emphasized, both of these directions could work at the same time.

What is important to stress in that respect, that bottom-up approach emphasizes external environmental influence on subjective well-being. Positive/negative outcomes of interaction with external environment lead to a higher/lower level of subjective well-being. In turn, top-down approach emphasizes personal traits. Individuals who are more inclinable to evaluate things positively will possess higher level of subjective well-being (Eid, 2008).

To explain this link between life satisfaction as a whole and satisfaction in the with the health in the context of top-down and bottom-up theories we employ Needs Conceptual Model of Subjective Well-Being, developed in A. Gataūlinas (2013) for his doctoral dissertation. To outline it briefly, the Needs Conceptual Model of Subjective Well-Being (NCM-SWB) consist on three types of theories, which could be named as:

1) Set point theories (Dynamic Equilibrium Theory and Homeostatic Theory).

2) Subjective well-being factors theories (Human Nature or Alternatively Livability Theory or Needs Theory; Relative Standards or Alternatively Comparison Theory).

3) Theories of needs (Maslow's Hierarchy of Needs Theory and Marxist Theory of Labor Power).

NCM-SWB embraces the idea of set point theories that under the normal life circumstances individual will possess the equilibrium state subjective well-being level as it is described in Dynamic Equilibrium Theory developed by Headey and Wearing $(1989,1992)$ or quite similarly individual will possess homeostatic state of the level of subjective well-being as it is described in Homeostatic Theory of Subjective Well-Being developed by R. Cummins $(1995,1998,2000,2003,2010)$. As well set-point theories state that equilibrium or homeostatic state of the level of subjective well-being varies across different people depending on the personality traits. Under normal life circumstances some individuals tend to be happier than others. Although this difference is in a certain defined range. R. Cummins goes even further to describe this range numerically, stating that the level of subjective well-being of a person living in Western societies under normal life circumstances will vary in a range of $70 \%-80 \%$ with the average being around $75 \%$. It is an open question what are those normal life circumstances and what leads the level of subjective well-being of an individual's in to that particular range. This could be seen from perspective of micro and macro level analysis. Personality traits are more expressed in the 
micro level analysis, which is based on opinion evaluations of separate people. Although when the macro level analysis takes in to account personal traits that are not so explicit, because it is based on averages within the countries.

In NCM-SWB, this open question is addressed by stressing needs satisfaction as a prime source of the level of subjective well-being that leads to equilibrium state. Indeed Maslow (2006) relates needs satisfaction with increased happiness, peace and rich internal life. Needs that are not satisfied, induce negative psychological reactions.

In the model there is a distinction between physiological and socially accepted needs. Physiological needs express those needs satisfaction or dissatisfaction of which makes individual physiologically comfortable or uncomfortable and they are related to human nature. Socially accepted needs express those needs satisfaction or dissatisfaction of which makes individual socially comfortable or uncomfortable and they are related to socialeconomic development of society. Thus the normal circumstances of life could be described as those that exist when the physiological and socially accepted needs of an individual are satisfied. The needs in NCM-SWB are interpreted as something that possesses objective nature depending on social-economic development of society. For instance one type of needs in its quantity and content are in the poorest nations of the World and other in the richest countries. This interpretation of the needs comes from the Marxist theory of value of labour power as it is defined by the sum of value of goods-commodities that individual uses for satisfaction of his/her needs. As K. Marx (1995) (Capital volume one, Buying and Selling Labour Power) shows the value of labour power and corresponding to it needs are determinated objectively and that corresponds to social-economic development of society.

Needs concept in NCM-SWB is closely related to Human Nature and Relative Standards theories of subjective well-being that were developed by Diener and Lucas (2000), Diener and Biswas-Diener (2002) and Veenhoven and Ehrhardt (1995). Human nature theory resembles importance of physiological needs satisfaction on subjective well-being of an individual. Relative Standards theory tends to stress socially accepted needs. Although in case of relative standards theory standard of comparison is understood in NCM-SWB not as something accidental as it is described in its original form, but as one that is objectively dependent on social-economic development of society.

Thus, the explanation of relation of health to satisfaction with life as a whole on the basis of NCM-SWB needs to consider how health is related to needs satisfaction and what role it plays in it. Emphasis on need satisfaction presupposes bottom-up direction of interrelation between satisfaction with health and satisfaction with life as a whole as a major factor and in turn, personality related top-down direction as minor factor. As it was indicated above, positive life outcomes (need satisfaction) determinate the satisfaction with life as a whole.

Interrelation between satisfaction with health and satisfaction with life as a whole could be depicted in a certain order (Figure 3). Satisfaction with health indicates how real life situation in the health domain is close to expectation based on certain standard such as individual's health condition in the past, expectations to possess certain health condition at certain age etc. Health condition comes as initial point, because an individual makes his/her satisfaction with health judgements based on more or less clearly perceived real life situation. At the end point individual's satisfaction with health through interaction with other domain satisfactions make an impact on satisfaction with life as a whole. Thus, the real health condition through satisfaction with it makes an impact on satisfaction with life as a whole.

Thus based on NCM-SWB rationale needs satisfaction determinates subjective well-being. In case of health domain its impact on life satisfaction as a whole obviously is not as forthright as in case of income and wealth, where purchasing power of an individual determinates his/her ability to satisfy needs. Health plays an important role in needs satisfaction in a couple of ways. Firstly, it creates physical or mental ability/inability to satisfy needs in a broad sense. Good health creates prerequisites to satisfy needs in a full extent. In turn, disability or impairment of body functions and disease creates an obstacle to satisfy human needs and in that sense it can reduce satisfaction with different life domains and with life as a whole. As well inability to satisfy needs can cause frustrations that could be the basis of negative emotions and mood. Secondly pain and uncomfort that is caused by a disease itself stimulate negative emotions and mood in an individual.

\section{Results}

As it was described in theoretical part of the article, we apply bottom-up approach to analyse the problem. That is we recognize that objective life domains-life circumstances are mirrored and evaluated by human con- 


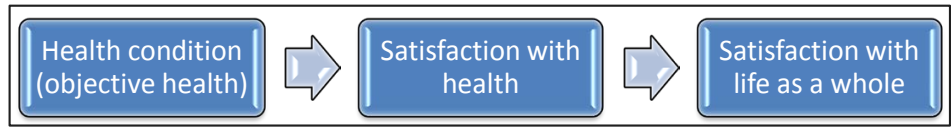

Figure 3. Interaction between subjective health and subjective well-being.

sciousness. The better or worse objective life circumstances the better or worse is satisfaction with them by an individual. As well according to Needs Conceptual Model of subjective well-being-satisfaction of physiological and socially acceptable needs is the way through which objective life circumstances shapes life satisfaction of an individual. The initial point in our theoretical framework is objective health and the end point is life satisfaction. Midpoint-satisfaction with health is intermediate link by which objective health situation impacts satisfaction with life as a whole.

\section{Objective Health}

In this part of the article, from the very general perspective, we are going to present objective health situation in EU countries. As indicators of objective health situation we use Eurostat data on percentage of people reporting a long standing illness or health problem indicator and as well data on percentage of people reporting a chronic disease. Those data for the EU countries are presented in Figure 4 and Figure 5 . As it is possible to indicate, there is no clear pattern of variation of objective health situation among EU countries according the social economic context of those countries. For instance, if we distinguish traditional market economy countries and former command economy countries, there is no regular difference between them in terms of objective health as measured by those indicators. As it is shown in Figure 4 such economically developed traditional market economy countries as Finland, Sweden, France or UK have quite large percentage of people reporting a longstanding illness or health problem, but some other traditional market economy countries like Belgium, Denmark or Luxemburg on average look quite healthy as measured by indicator. Analogous situation could be observed in case of former command economy countries. Some of these countries like Lithuania, Czech Republic, Bulgaria doing quite well in terms of objective health, but some other former command economy countries such as Hungary, Estonia, and Slovenia have relatively large percentage of people reporting long standing illness or health problem. The similar tendency could be observed in Figure 5, where percentage of people reporting chronic disease is depicted. From this data it seems obvious that social-economic development has nothing to do with the situation of objective health in the EU. Correlation analysis that involved estimation of interrelation between median equivalised net income and inequality of income on the one side and the objective health indicators on the other confirmed that. As well there were tested how objective health as expressed by the mentioned indicators depend on age structure and average life expectancy of society, because it's possible to think that the countries that have older population could have higher percentage of people that report long standing illness or health problem. Although correlation analysis proved that it's not the case for the EU countries. The life style indicators might explain this, but Eurostat does not provide sufficient data to evaluate that across all the EU countries.

From what was explained above it would be wrong to conclude that objective health does not show any meaningful pattern such as the one depending on social-economic context of a society. If we take different measure of objective health such as average life expectancy of people in the EU countries, then there is clear pattern of association between social economic development of an EU country and objective health of its population. People in traditional market economy countries have a tendency to possess higher average life expectancy then the EU average. And in turn people in former command economy countries have a tendency to possess an average life expectancy that is lower than the EU average (Figure 6).

The correlation-regression analysis portrays the relationship between median equivalised net income and average life expectancy for the EU countries (Figure 7). The figure shows that the higher median income for the country, the higher life expectancy of its population.

Overall results on data analysis show different tendencies. If data on percentage of people, who report a long standing illness and health problem or data on percentage of people, who report chronic disease are considered, then there is no clear pattern of variation of objective health between EU countries in the context of social-economic development or other excepted demographic variables.

But if the data on life expectancy as a measure of objective health is considered than there is a clear pattern in the context of social economic development—-traditional market economy countries possess life expectancy that 


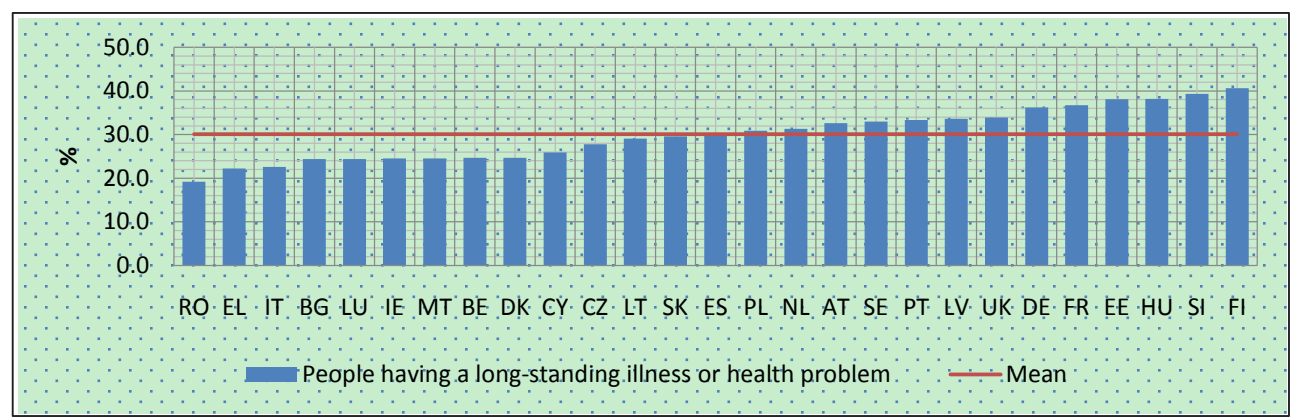

Figure 4. Objective health as measured by percentage of people having long-standing illness or health problem for the EU countries, 2008. Source: Eurostat.

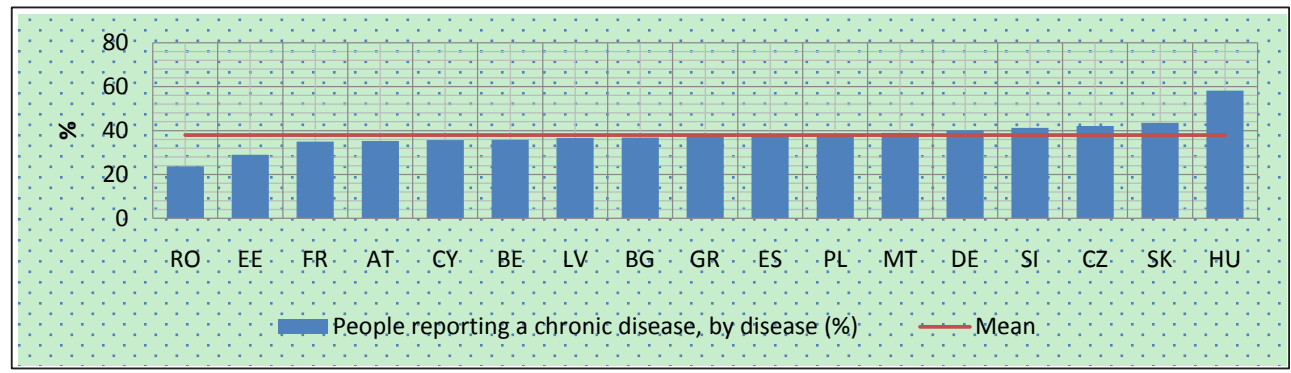

Figure 5. Objective health as measured by percentage of people reporting a chronic disease for the EU countries, 2008. Source: Eurostat.

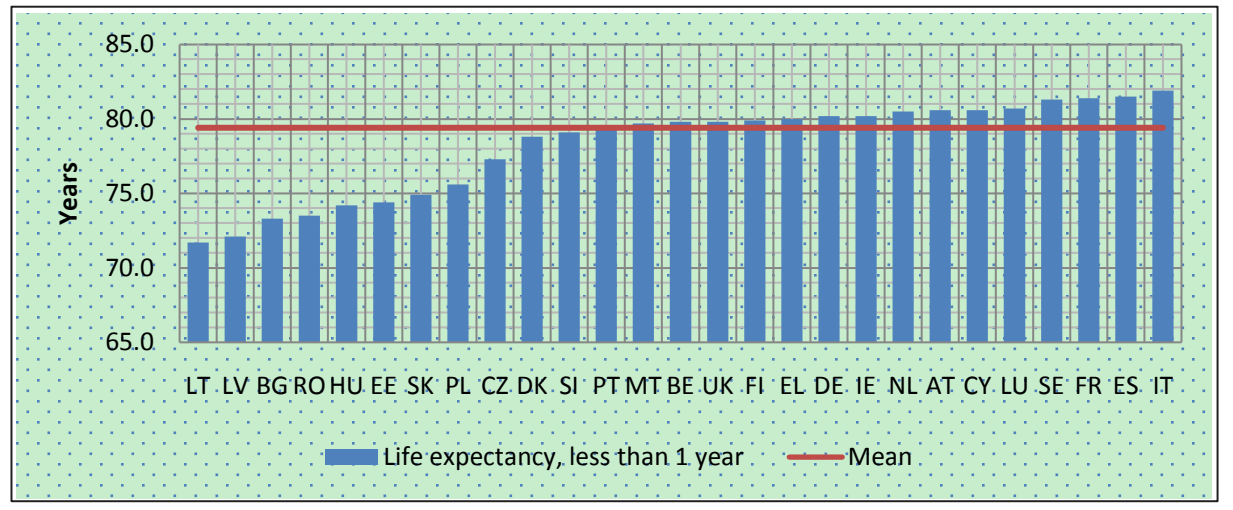

Figure 6. Average life expectancy for the EU countries, 2008. Source: Eurostat.

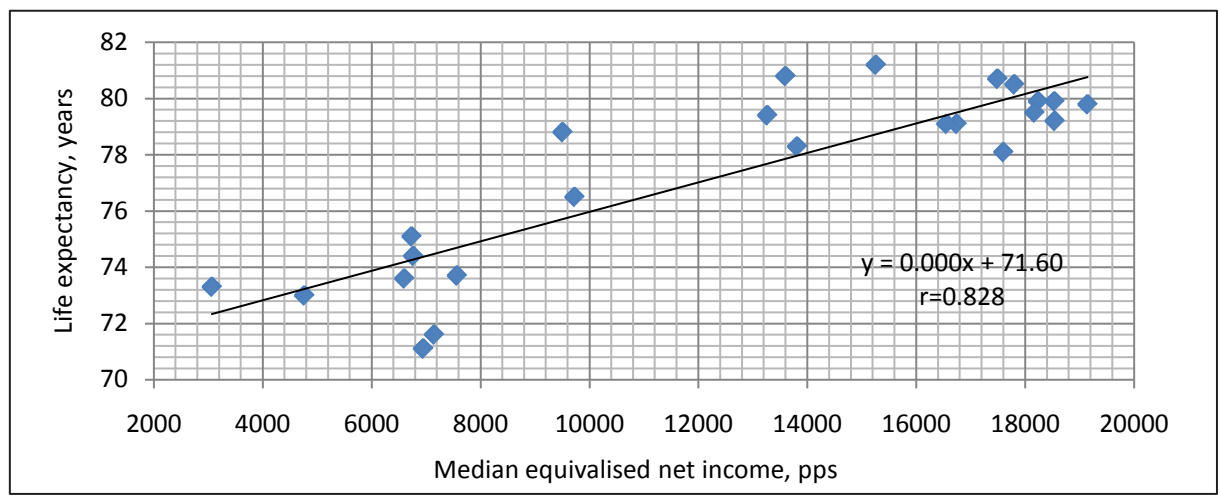

Figure 7. Interrelation between life expectancy and monthly household income. Source: Eurostat. 
is higher than EU average and the former command economy countries have average life expectancy that is lower than EU average. Thus life expectancy is strongly correlated with medina income for the EU countries. The one possible explanation for those different tendencies is that illness, health problems and chronic disease are mainly impacted by the physiological causes and does not much depend on better possibilities for the higher quality of life for people that are available in more economically developed countries. Although those adverse health conditions such as long standing illness, health problems and chronic disease are managed better in more economically developed traditional market economy countries than in less economically developed former command economy countries.

\section{Subjective Health}

In this part of the article we are going to describe subjective health situation and its relation to objective health in EU countries. We use EVS and Eurostat data on subjective health. As was mentioned in theoretical part of this article, subjective health indicates individual's situation with health from his/her own perspective. In this article subjective health is perceived as satisfaction with health.

As it is shown in Figure 8 there is a certain pattern in variation of average satisfaction with health between EU countries. This pattern is different from the objective health in terms of percentage of people, reporting long standing illness or health problems or in terms of the percentage of people reporting chronic diseases. Although satisfaction with health pattern among EU countries is quite similar to objective health pattern in terms of the average life expectancy in EU countries. The countries that have average satisfaction with health level below the EU mean are mainly the countries of former command economy. In turn the countries that have average life satisfaction above the EU average are mainly ones that are of traditional market economy. Thus there is a clear regional clusters within EU space: cluster of traditional marked economy countries that possesses high average satisfaction with health and cluster of former command economy countries that possesses low average satisfaction with health. The same pattern could be indicated by the satisfaction with health data provided by Eurostat (Figure 9).

The tendency of interrelation between satisfaction with health and average life expectancy could be estimated by the methods of correlation-regression analysis. There is a strong interrelation between life expectancy and satisfaction with health (Figure 10). In the EU countries where the average life expectancy is large, average satisfaction with health tends to be larger as well. Looking from the perspective of bottom up approach the objective life situation - the domain of health determinates satisfaction with them. The other two measures of objective health such as percentage of people who have a long-standing illness or health problem or percentage of people reporting a chronic disease does not correlate with subjective health.

\section{Empirical Results—Life Satisfaction}

The pattern of life satisfaction among the EU countries reminds the pattern of variation of satisfaction with health and the pattern of average life expectancy (Figure 11). Traditional market economy countries have life satisfaction that is above the EU average and the former command economy countries have average life satisfaction that is bellow EU average.

Correlation-regression analysis allows to indicate the interrelation between satisfaction with health and satisfaction with life as a whole (Figure 12). In the countries, where the average satisfaction with health is higher, the overall life satisfaction tends to be higher too. The correlation on a micro level or in other words on a level of separate individuals is much smaller, than on a macro level portrayed in a Figure 12 and is equal to 0.37 . This correlation is still significant in terms of its size. Micro level correlation is smaller, because on a micro level personality traits exert influence on the way how people evaluate their health and life as a whole. Health domain is not equally important in terms of its influence on overall life satisfaction for separate individuals.

\section{Conclusion}

Explanation of interrelation between subjective health and subjective well-being based on Needs Conceptual Model of Subjective Well-Being would suggest that the health affects the overall level of satisfaction with life through its role in satisfaction of needs. Health creates physical or mental ability/inability to satisfy needs in a broad sense. Good health creates prerequisites to satisfy needs in a full extent. In turn, disability or impairment 


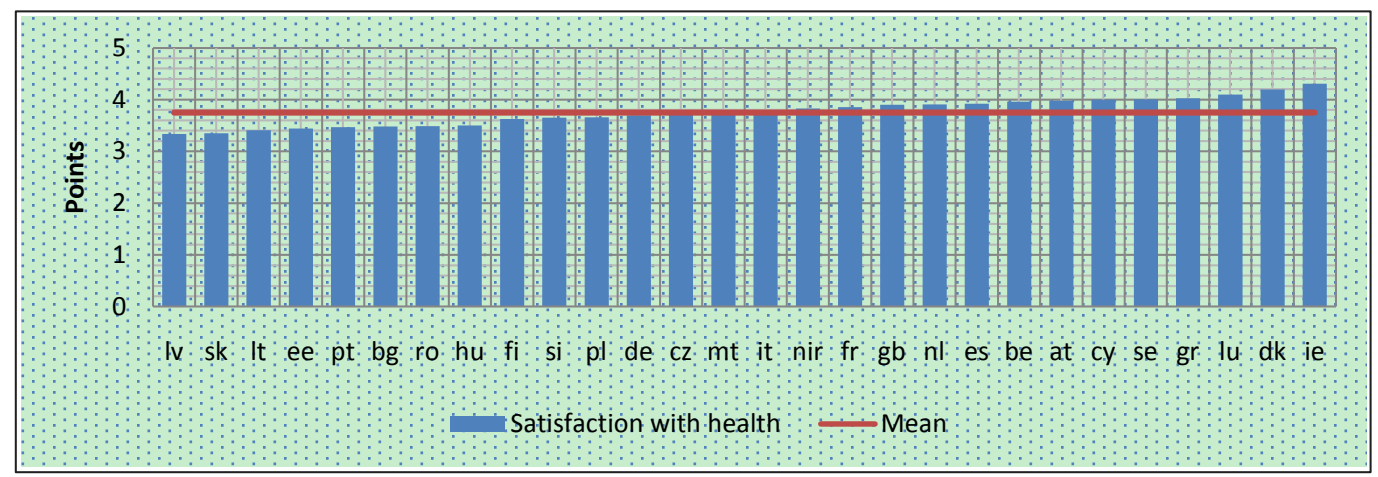

Figure 8. Satisfaction with health in EU countries 2008-2009. Source: calculation based on European Values Study data. Scale: 5 point scale, the higher the point for the country the higher the average satisfaction with health in the country.

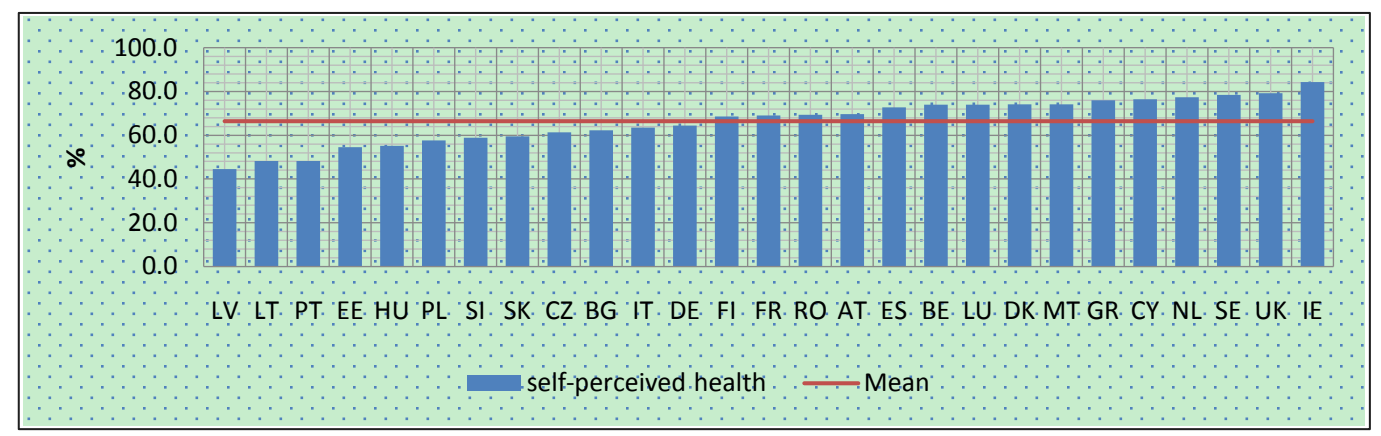

Figure 9. Percentage of people satisfaction with their health in EU countries, 2008. Source: Eurostat.

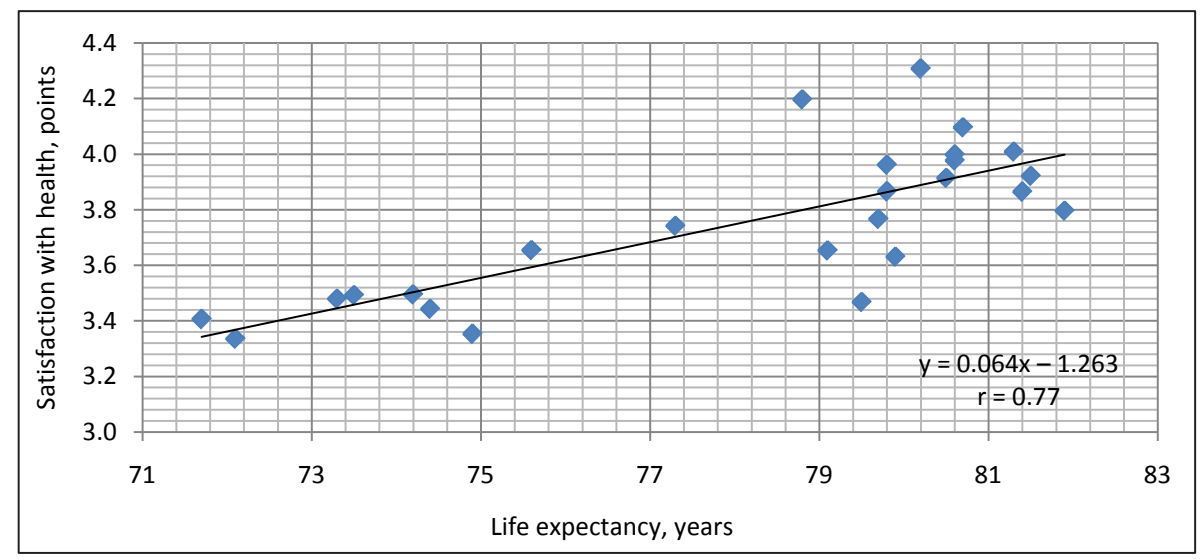

Figure 10. Interrelation between life expectancy and the satisfaction with health, 2008-2009. Source: calculation based on European Values Study and Eurostat data.

of body functions and disease creates an obstacle to satisfy human needs and in that sense it can reduce satisfaction with different life domains and with life as a whole. Inability to satisfy needs can cause frustrations that could be the basis of negative emotions and mood. As well pain and uncomfort that could be associated with bad health can be the source of negative emotions and mood of an individual. The needs in context of the conceptual model should be understood in a double sense. For an individual it is essential to satisfy no tony physiological needs and socially acceptable needs as well. Social economic development of society can be the source of new needs that are socially essential for an individual to satisfy them.

Empirical results of this article reveal that subjective health as measured by life satisfaction is related to objective health estimated as life expectancy. The higher average life expectancy in a EU country, the higher av- 


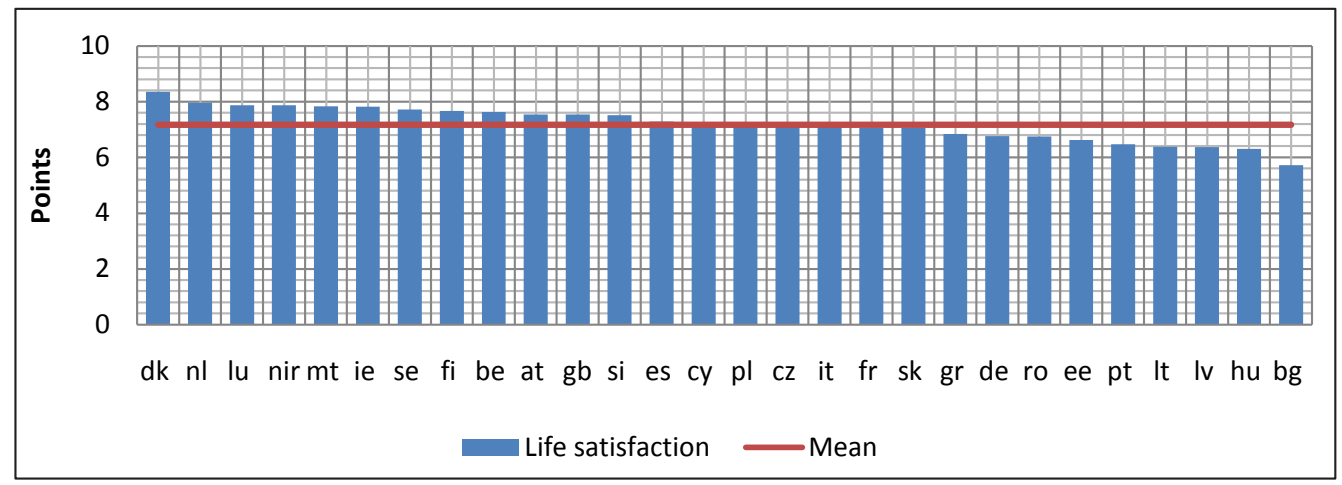

Figure 11. Average life satisfaction in EU countries, 2008-2009. Source: calculation based on European Values Study data. Scale: 10 point scale, the higher the point for the country the higher the average satisfaction with health in the country.

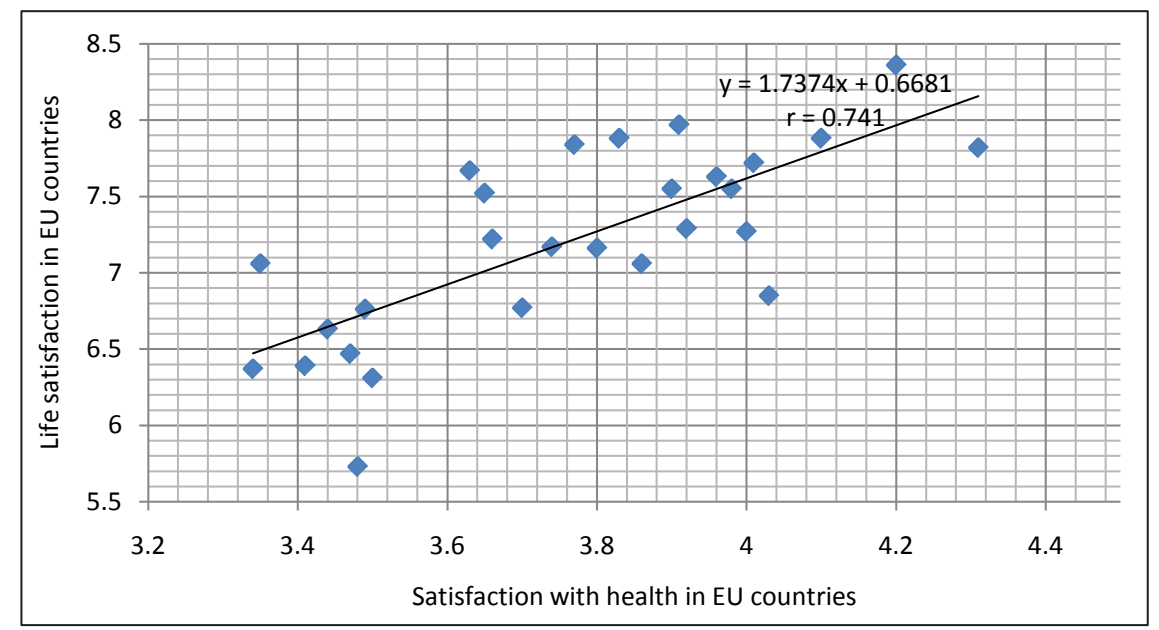

Figure 12. Interrelation between satisfaction with life and satisfaction with health, 20082009. Source: calculation based on European Values Study data.

erage satisfaction with health. Life expectancy is a good predictor of satisfaction with health on a macro level. In turn, average life expectancy of a society is related to its social-economic development. The EU countries that have higher per capita income tend to have large average life expectancy of their societies. Thus in this article we defend bottom up approach as a main direction of interaction between satisfaction with health domain and life satisfaction as whole. That is people make judgments about their health based the objective health condition. In turn the satisfaction with health is a significant determinant of satisfaction with life as a whole. Although in this article we do not deny that personality traits might modify the interaction between satisfaction with health and life satisfaction. Personality type that tends to be extraverted would evaluate things more positively than personally type that is peculiar to neurotics.

\section{References}

Bendelow, G. (2009). Health, Emotion and the Today. Cambridge: Polity Press.

Beverley, A. S. (2008). Well-Being: In Search of a Good Life? Cambridge: Policy Press.

Boarini, R., Comola, M., Smith, C., Manchin, R., \& Keulenaer, F. (2012). What Makes for a Better Life: The Determinants of Subjective Well-Being in OECD Countries-Evidence from the Gallup World Poll. OECD Statistical Working Papers, 2012/03. OECD Publishing. http://dx.doi.org/10.1787/5k9b9ltjm937-en

Bradburn, N. (1969). The Structure of Psychological Well-Being. Chicago: Aldine Pub. Co.

Cottam, H. R., \& Mangus, A. R. (1942). A Proposed Definition of Standard of Living. Social Forces, 21, 177, 179.

http://dx.doi.org/10.2307/2570553 
Cummins, R. A. (1995). On the Trail of the Gold Standard for Life Satisfaction. Social Indicators Research, 35, $179-200$. http://dx.doi.org/10.1007/BF01079026

Cummins, R. A. (1998). The Second Approximation to an International Standard for Life Satisfaction. Social Indicators Research, 43, 307-334. http://dx.doi.org/10.1023/A:1006831107052

Cummins, R. A. (2000). Personal Income and Subjective Well-Being: A Review. Journal of Happiness Studies, 1, 133-158. http://dx.doi.org/10.1023/A:1010079728426

Cummins, R. A. (2003). Normative Life Satisfaction: Measurement Issues and a Homeostatic Model. Social Indicators Research, 64, 225-256. http://dx.doi.org/10.1023/A:1024712527648

Cummins, R. A. (2010). Subjective Well-Being, Homeostatically Protected Mood and Depression: A Synthesis. Journal of Happiness Studies, 11, 1-17. http://dx.doi.org/10.1007/s10902-009-9167-0

DeSalvo, K. B., Fan, V. S., McDonell, M. B., \& Fihn, S. D. (2005). Predicting Mortality and Healthcare Utilization with a Single Question. Health Services Research, 40, 1234-1246. http://dx.doi.org/10.1111/j.1475-6773.2005.00404.x

Diener, E. (1984). Subjective Well-Being. Psychological Bulletin, 95, 542-575. http://dx.doi.org/10.1037/0033-2909.95.3.542

Diener, E. (2006). Guidelines for National Indicators of Subjective Well-Being and Ill-Being. Applied Research in Quality of Life, 1, 151-157. http://dx.doi.org/10.1007/s11482-006-9007-x

Diener, E., \& Biswas-Diener, R. (2002). Will Money Increase Subjective Well-Being? Social Indicators Research, 57, 119169. http://dx.doi.org/10.1023/A:1014411319119

Diener, E., \& Lucas, R. E. (2000). Explaining Differences in Societal Levels of Happiness: Relative Standards, Need Fulfilment, Culture, and Evaluation Theory. Journal of Happiness Studies, 1, 41-78. http://dx.doi.org/10.1023/A:1010076127199

Diener, E., Lucas, R., Schimmack, U., \& Helliwell, J. (2009). Well-Being for Public Policy. Oxford: Oxford University Press. http://dx.doi.org/10.1093/acprof:oso/9780195334074.001.0001

Eid, M. (2008). Measuring the Immeasurable: Psychometric Modelling of Subjective Well-Being Data. In M. Eid, \& R. J. Larsen (Eds.), The Science of Subjective Well-Being (pp. 141-167). New York: The Guilford Press.

Fotso, J. C., \& Kuate-Defo, B. (2005). Measuring Socioeconomic Status in Health Research in Developing Countries: Should We Be Focusing on Households, Communities or Both? Social Indicators Research, 72, 189-237. http://dx.doi.org/10.1007/s11205-004-5579-8

French, D., Vedhara, K., Kaptein, A. A., \& Weinman, J. (2010). Health Psychology. USA: Blackwell Publishing Ltd.

Galinha, J., \& Pais-Ribeiro, J. L. (2011). Cognitive, Affective and Contextual Predictors of Subjective Wellbeing. International Journal of Wellbeing, 2, 34-53. http://dx.doi.org/10.5502/ijw.v2i1.3

Gallagher, M. W., Lopez, S., \& Preacher, K. J. (2009). The Hierarchical Structure of Well-Being. Journal of Personality, 77, 1025-1050. http://dx.doi.org/10.1111/j.1467-6494.2009.00573.x

Gataūlinas, A. (2013). Lietuvos visuomenès subjektyvioji gerové Europos Sajungos šalių kontekste. Doctoral Thesis, Vilnius: Vilnius University.

Headey, B. W., \& Wearing, A. J. (1989). Personality, Life Events and Subjective Well-Being: Towards a Dynamic Equilibrium Model. Journal of Personality and Social Psychology, 57, 731-739. http://dx.doi.org/10.1037/0022-3514.57.4.731

Headey, B. W., \& Wearing, A. J. (1992). A Theory of Subjective Well-Being. Melbourne: Longman Cheshire.

Johnston, D. W., Propper, C., \& Shields, M. A. (2007). Comparing Subjective and Objective Measures of Health: Evidence from Hypertension for the Income/Health Gradient. IZA DP No. 2737.

Kahneman, D., Diener, E., \& Schwarz, N. (2003). Well-Being: The Foundations of Hedonic Psychology. New York: Russel Sage Foundation.

Killoran, A., \& Kelly, M. P. (2010). Evidence-Based Public Health: Effectiveness and Efficiency. Oxford: Oxford University Press.

Levenstein, C., \& Wooding, J. (1997). Work, Health, and Environment: Old Problems, New Solutions. New York: Guilford Publications.

Liu, X. (2012). Survival Analysis: Models and Applications. UK: Higher Education Press. http://dx.doi.org/10.1002/9781118307656

Lucas, R. (2004). Top-Down and Bottom-Up Models of Life Satisfaction Judgments. The 6th International German SocioEconomic Panel Study User Conference, 26 June 2004. http://www.diw.de/documents/dokumentenarchiv/17/41891/paper2004_lucas.pdf

Marx, K. (1995). Capital, Volume One. The Buying and Selling of Labour-Power. Marx/Engels Marxist Internet Archive. www.marxists.org 
Maslow, A. (2006). Motyvacija ir asmenybe. Vilnius: Apostrofa.

McCracken, K., \& Phillips, D. R. (2012). Global Health: An Introduction to Current and Future Trends. London: Routledge.

McDowel, I. (2006). Measuring Health: A Guide to Rating Scales and Questionnaires. Oxford: Oxford University Press. http://dx.doi.org/10.1093/acprof:oso/9780195165678.001.0001

Pardeck, J. T., Longino, C. F., \& Murphy, J. W. (1998). Reason and Rationality in Health and Human Services Delivery. Philadelphia: The Haworth Press.

Pavot, W. (2008). The Assessment of Subjective Well-Being: Successes and Shortfalls. In M. Eid, \& R. J. Larsen (Eds.), The Science of Subjective Well-Being (pp. 124-140). New York: The Guilford Press.

Schimmack, U. (2008). The Structure of Subjective Well-Being. In M. Eid, \& R. J. Larsen (Eds.), The Science of Subjective Well-Being (pp. 97-123). New York: The Guilford Press.

Siegel, P. Z. (1994). Self-Reported Health Status: Public Health Surveillance and Small-Area Analysis. In S. Schechter (Ed.), Proceedings of the 1993 NCHS Conference on the Cognitive Aspects of Self-Reported Health Status. NCHS Working Paper Series, No. 10.

Sīlis, V. (2010). Latvijasiedzīvotājuveselībasuzvedībaundzīveskvalitāte (Promocijasdarbs). Rīga: Rīgas Stradiṇuuniversitāte.

Snyder, C. R., \& López, S. J. (2009). Oxford Handbook of Positive Psychology. New York: Oxford University Press.

Stewart, A. L., \& Ware, J. E. (1998). Measuring Functioning and Well-Being: The Medical Outcomes Study Approach. Durham: Duke University Press.

Titterton, M. (2005). Risk and Risk Taking in Health and Social Welfare. London: Jessica Kingsley Publishers.

Veenhoven, R., \& Ehrhard, J. (1995). The Cross-National Pattern of Happiness: Test of Predictions Implied in Three Theories of Happiness. Social Indicators Research, 34, 33-68. http://dx.doi.org/10.1007/BF01078967

Vitters $\varnothing$, J., \& Nilsen, F. (2002). The Conceptual and Relational Structure of Subjective Well-Being, Neuroticism, and Extraversion: Once Again, Neuroticism Is the Important Predictor of Happiness. Social Indicators Research, 57, 89-118. http://dx.doi.org/10.1023/A:1013831602280

Wahl, H. W. (2006). The Many Faces of Health, Competence and Well-Being in Old Age: Integrating Epidemiological, Psychological and Social Perspectives. Berlin: Springer. http://dx.doi.org/10.1007/1-4020-4138-1

World Health Organization (1946). Official Records of the World Health Organization. Geneva: World Health Organization. 
Scientific Research Publishing (SCIRP) is one of the largest Open Access journal publishers. It is currently publishing more than 200 open access, online, peer-reviewed journals covering a wide range of academic disciplines. SCIRP serves the worldwide academic communities and contributes to the progress and application of science with its publication.

Other selected journals from SCIRP are listed as below. Submit your manuscript to us via either submit@scirp.org or Online Submission Portal.
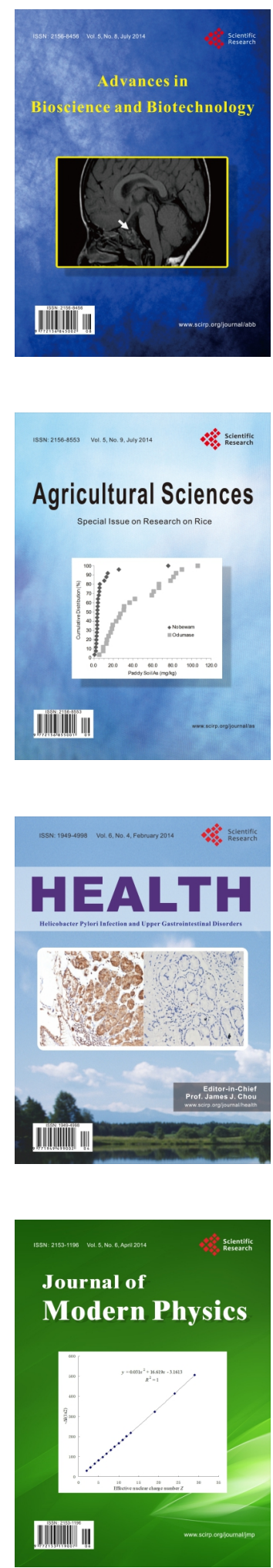
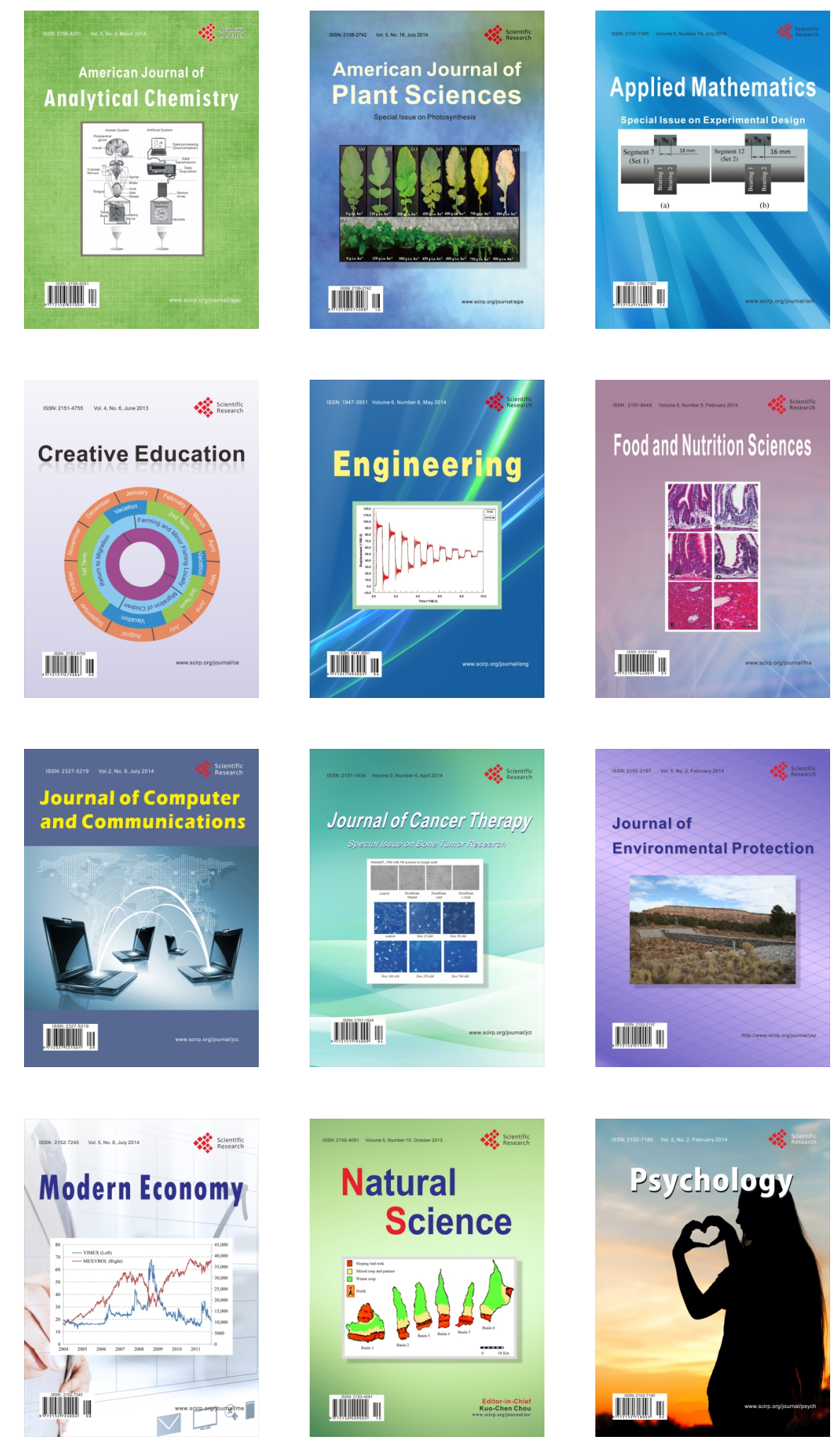